\title{
The International Consortium of Lithium Genetics (ConLiGen): Achievements and Collaborations
}

\author{
Heilbronner U., $\mathrm{PhD}$ \\ Institute of Psychiatric Phenomics and Genomics (IPPG), University Hospital, LMU Munich
}

\begin{abstract}
Summary. Lithium is an indispensable tool of modern psychiatry. Although it is well-known that response to lithium is a familial trait, available research on pharmacogenetics regarding lithium treatment has, in the past, produced few reproducible results. The Consortium of Lithium Genetics (ConLiGen) was initiated by Thomas G. Schulze and Francis J. McMahon in 2008 to overcome these limitations. To date, researchers from 39 countries have joined the consortium, making it a truly international effort. A hallmark of the consortium is the use of an 11-point lithium response rating scale defined by Martin Alda and colleagues. The pooling of genotype data from over 2,500 patients phenotyped with this standardized response scale, have led to initial successes, which form the basis for further research.
\end{abstract}

Keywords: bipolar disorder; medication; collaboration, GWAS; response; ALDA scale; genomics.

\section{Международный консорциум генетики лития (ConLiGen): достижения и сотрудничество}

\author{
Хейлброннер У., к.м.н. \\ Институт психиатрической геномики и феномики, Университетский госпиталь, \\ Мюнхенский университет Людвига-Максимилиана
}

\begin{abstract}
Резюме. Литий является незаменимым инструментом современной психиатрии. Хотя общеизвестно, что ответ на терапию литием является наследуемой чертой, имеющиеся исследования фармакогенетики терапии лечения литием в прошлом дали мало воспроизводимых результатов. Консорциум генетики лития (ConLiGen) был создан Thomas G. Schulze и Francis J. McMahon в 2008 году для преодоления этих ограничений. В настоящее время исследователи из 39 стран присоединились к консорциуму, что делает его по-настоящему международным мероприятием. Отличительной чертой консорциума является использование 11-балльной шкалы ответа на терапию литием, сформированной Маrtin Alda и его коллегами. Объединение данных по генотипам более чем 2500 пациентов, фенотипированных при помощи этой стандартизированной шкалы ответов, привело к первоначальным успехам, которые формируют основу для дальнейших исследований.
\end{abstract}

Ключевые слова: биполярное расстройство, препараты, GWAS, терапевтический ответ, шкала ALDA, геномика.

$\mathrm{L}$ ithium has been successfully used to treat bipolar disorder for more than 50 years. Apart from its proven antimanic and prophylactic effects, there is also evidence that suggests an antisuicidal effect in affective disorders, making it an indispensable tool of modern psychiatry (Papiol, Schulze, \& Alda, 2018). However, response to lithium is variable, with only about $30 \%$ of bipolar patients responding to treatment (Garnham et al., 2007). Although it is well-known that response to lithium is a familial trait (e.g. Grof et al., 2002), available research on pharmacogenetics regarding lithium treatment has, in the past, produced few reproducible results (see e.g. Pisanu, Heilbronner, \& Squassina, 2018). To overcome this limitation, ConLiGen was initiated by Thomas G. Schulze and Francis J. McMahon at the National Institutes of Health, USA, based upon a meeting which took place at NIMH on May 6, 2008 (Schulze et al., 2010). ConLiGen aims to identify genetic determinants of response to lithium treatment in bipolar disorder, as well as genetic determinants of adverse events emerging during lithium treatment. To date, researchers from 39 countries have joined the consortium, making it a truly international effort. As response phenotype for lithium treatment, ConLiGen has been using an 11-point rating scale defined by Martin Alda and colleagues (Grof et al., 2002). While an important goal of ConLiGen is to further study this response phenotype (Manchia et al., 2013; Scott et al., 2019), another focus is to facilitate well-powered genome-wide association studies (GWAS). In an initial effort (Hou, Heilbronner, et al., 2016), data from over 20 clinical centers have been pooled to perform an initial GWAS of more than 2,500 individuals in which lithium response had been measured. This study identified four SNPs associated with response to lithium. Furthermore, ConLiGen data has been used in several additional publications (Amare et al., 2018; Hou, Bergen, et al., 2016; Kalman et al., 2019; Reinbold et al., 2018). In the future ConLiGen's focus will be on expanding internationally, collecting more lithium response data and biomaterial to replicate previous findings. Also, another aim is more comprehensive phenotyping, to develop predictive models of lithium response. 


\section{References}

1. Amare A.T., Schubert K.O., Hou L., Clark S.R., Papiol S., Heilbronner U., ... Baune B.T. Association of Polygenic Score for Schizophrenia and HLA Antigen and Inflammation Genes With Response to Lithium in Bipolar Affective Disorder: A Genome-Wide Association Study. JAMA Psychiatryю 2018;75(1):65-74. https://doi.org/10.1001/jamapsychiatry.2017.3433

2. Garnham J., Munro A., Slaney C., Macdougall M., Passmore M., Duffy A., ... Alda M. Prophylactic treatment response in bipolar disorder: Results of a naturalistic observation study. Journal of Affective Disorders. 2007;104(1-3):185-190. https://doi. org/10.1016/j.jad.2007.03.003

3. Grof P., Duffy A., Cavazzoni P., Grof E., Garnham J., MacDougal, M., ... Alda M. Is response to prophylactic lithium a familial trait? The Journal of Clinical Psychiatry. 2002;63(10):942-947. https:// doi.org/10.4088/jcp.v63n1013

4. Hou L., Bergen S.E., Akula N., Song J., Hultman C.M., Landén M., ... McMahon F.J. Genome-wide association study of 40,000 individuals identifies two novel loci associated with bipolar disorder. Human Molecular Genetics. 2016;25(15):3383-3394. https://doi.org/10.1093/hmg/ddw181

5. Hou L., Heilbronner U., Degenhardt F., Adli M., Akiyama K., Akula N., ... Schulze T.G. Genetic variants associated with response to lithium treatment in bipolar disorder: A genome-wide association study. The Lancet. 2016;387(10023):1085-1093. https://doi.org/10.1016/S0140-6736(16)00143-4

6. Kalman J.L., Papiol S., Forstner A.J., Heilbronner U., Degenhardt F., Strohmaier J., ... Schulze T. G. Investigating polygenic burden in age at disease onset in bipolar disorder: Findings from an international multicentric study. Bipolar Dis- orders. 2019;21(1):68-75. https://doi.org/10.1111/ bdi. 12659

7. Manchia M., Adli M., Akula N., Ardau R., Aubry J.-M., Backlund L., ... Alda M. Assessment of Response to Lithium Maintenance Treatment in Bipolar Disorder: A Consortium on Lithium Genetics (ConLiGen) Report. PLoS ONE. 2013;8(6):e65636. https://doi.org/10.1371/journal.pone.0065636

8. Papiol S., Schulze T.G., Alda M. Genetics of Lithium Response in Bipolar Disorder. Pharmacopsychiatry. 2018;51(5):206-211. https://doi. org/10.1055/a-0590-4992

9. Pisanu C., Heilbronner U., Squassina A. The Role of Pharmacogenomics in Bipolar Disorder: Moving Towards Precision Medicine. Mol Diagn Ther. 2018;22(4):409-420. https://doi.org/10.1007/ s40291-018-0335-y

10. Reinbold C. S., Forstner A. J., Hecker J., Fullerton J. M., Hoffmann P., Hou L., ... Cichon S. Analysis of the Influence of microRNAs in Lithium Response in Bipolar Disorder. Front Psychiatry. 2018;9:207. https://doi.org/10.3389/fpsyt.2018.00207

11. Schulze T.G., Alda M., Adli M., Akula N., Ardau R., Bui E.T., ... McMahon F.J. The International Consortium on Lithium Genetics (ConLiGen): An initiative by the NIMH and IGSLI to study the genetic basis of response to lithium treatment. Neuropsychobiology. 2010;62(1):72-78. https://doi. org/10.1159/000314708

12. Scott J., Etain B., Manchia M., Brichant-Petitjean C., Geoffroy P., Schulze T., ... ConLiGen collaborators. An examination of the quality and performance of the Alda scale for classifying lithium response phenotypes. Bipolar Disorders. 2019; https:// doi.org/10.1111/bdi.12829

\section{Сведения об авторах}

Urs Heilbronner - PhD, Institute of Psychiatric Phenomics and Genomics (IPPG), University Hospital, LMU Munich 